\title{
Traumatic dental extraction with severe complications
}

\author{
Urazowa ekstrakcja zęba z ciężkimi powikłaniami
}

Department of Otorhinolaryngology, Hospital Selayang, Lebuhraya Selayang-Kepong, 68100 Batu Caves, Selangor, Malaysia

Correspondence: Jeyasakthy Saniasiaya, MD, MMED (ORL-HNS), Department of Otorhinolaryngology, Hospital Selayang, Lebuhraya Selayang-Kepong, 68100 Batu Caves, Selangor, Malaysia,

e-mail:shakthy_18@yahoo.com

Abstract Parapharyngeal abscess is a serious life-threatening complication of dental infection which warrants immediate surgical intervention and management. Dental infections leading to parapharyngeal abscess are not uncommon. Herein, we are reporting the case of an elderly man who presented with left cheek swelling post dental extraction which led to an extensive parapharyngeal abscess with airway obstruction. The patient required incision and drainage twice, and the complication subsequently resolved with dressing and intravenous antibiotics. Despite being a common procedure, dental extraction ought to be performed with care due to its potentially devastating complications, as in our case.

Keywords: dental extraction, dental abscess, parapharyngeal abscess

Streszczenie Ropień przestrzeni przygardłowej jest poważnym, zagrażającym życiu powikłaniem zakażeń pochodzenia zębowego, wymagającym niezwłocznej interwencji chirurgicznej i leczenia. Rozwój ropnia przestrzeni przygardłowej w następstwie zakażenia zębopochodnego nie jest w praktyce klinicznej zjawiskiem rzadkim. W pracy opisano przypadek starszego mężczyzny, u którego po ekstrakcji zęba wystąpił obrzęk lewego policzka oraz rozległy ropień w obrębie przestrzeni przygardłowej z towarzyszącą niedrożnością dróg oddechowych. U pacjenta wykonano dwukrotne nacięcie i drenaż ropnia oraz zaopatrzenie rany. Zastosowano dożylne leczenie antybiotykami. Choć ekstrakcja zęba jest rutynowym zabiegiem stomatologicznym, niezbędne jest zachowanie ostrożności podczas jego wykonywania ze względu na ryzyko ciężkich powikłań, jak w przedstawionym przypadku.

Słowa kluczowe: ekstrakcja zęba, ropień zębowy, ropień przestrzeni przygardłowej 


\section{INTRODUCTION}

$\mathrm{D}$ eep neck space infections are often linked to oropharyngeal or odontogenic infections, trauma or prior surgery involving the head and neck region. Apart from that, these infections are usually polymicrobial bacterial infections, with Staphylococcus and Streptococcus being the most common pathogens isolated ${ }^{(1-3)}$. A deep neck space infection in the form of a parapharyngeal abscess following dental extraction is not uncommon. Patients may present with fever, odynophagia and neck swelling days after dental extraction, which may be overlooked by attending physicians. This paper describes the case of a parapharyngeal abscess complicated from a traumatic lower molar extraction, and presents a literature review

\section{CASE REPORT}

A 60-year-old man with underlying type 2 diabetes mellitus presented to the emergency department with a 10-day history of painful left cheek swelling. The patient reported that he had a lower tooth extraction done at a private clinic prior to the presentation. According to the patient, multiple attempts were undertaken for the extraction of his left lower molar, and he was discharged home with oral antibiotics. Three days after the extraction, he developed left cheek swelling which lead him to another private clinic for consultation. He was, however, discharged home with oral amoxicillin/clavulanic acid. Nevertheless, to his dismay, the cheek swelling became even bigger and more painful. Besides the cheek swelling, there was dysphagia, odynophagia, and shortness of breath.

Upon examination, the patient was not septic looking, with no audible stridor. A huge left cheek swelling was noted, which was firm, tender, with inflamed overlying skin, measuring $8 \times 6 \mathrm{~cm}$. Trismus was present as a result of the swelling. An intraoral examination revealed painful swelling over the left lower alveolus, and left peritonsillar bulge along with mild medialization of the lateral pharyngeal wall. No pus discharge was seen from site 38 , which corresponded to the previous extraction site. A neck examination revealed no palpable mass, with intact laryngeal framework. Besides that, nasal and ear examinations were unremarkable. Bedside flexible nasopharyngolaryngoscopy revealed medialisation of the lateral pharyngeal wall with no pus noted, with intact airway. Otherwise, the patient's vital signs and other systemic examinations were unremarkable.

The patient was admitted, and intravenous cefuroxime and metronidazole were commenced. Computed tomography (CT) scan of the face and neck was done, and revealed a collection in the left buccal space extending into the left peritonsillar and parapharyngeal space. Incision and drainage of the left peritonsillar abscess revealed min pus. Overnight, the patient developed exacerbation of the swelling, with shortness of breath. The oxygen saturation was

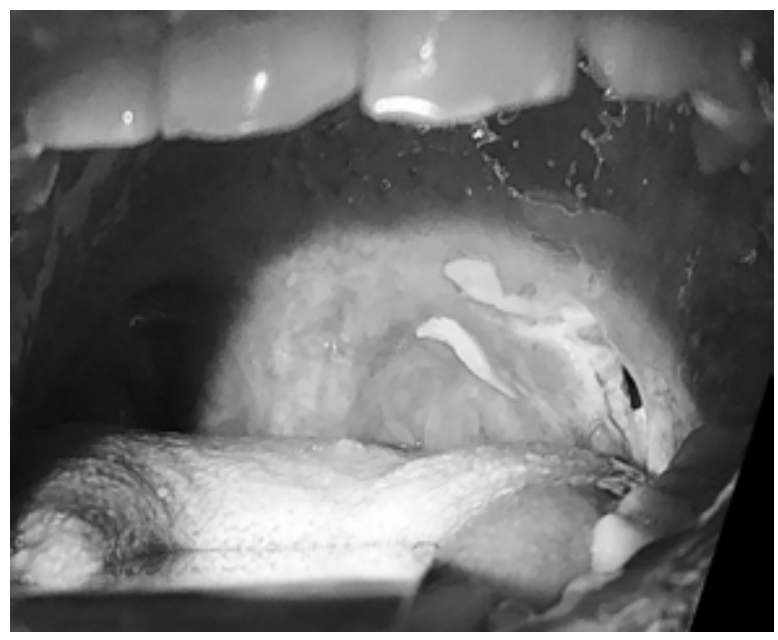

Fig. 1. Left peritonsillar incision and drainage site

scheduled for emergency incision and drainage under general anaesthesia.

Intraoperatively, intraoral incision and drainage were performed. A nick was made over the anterior pillar, which drained $100 \mathrm{cc}$ of foul-smelling thick pus (Fig. 1). The incision site was opened up to the superior constrictor muscle, and flushed with povidone. The incision site was later packed with ribbon gauze soaked with povidone, and the patient was kept intubated overnight. A Ryles tube was inserted for feeding, which was started the following day.

The following day, the ribbon gauze was removed, and the patient was successfully extubated. Flushing with diluted povidone was done daily. However, 3 days post incision and drainage, the patient developed worsening submental

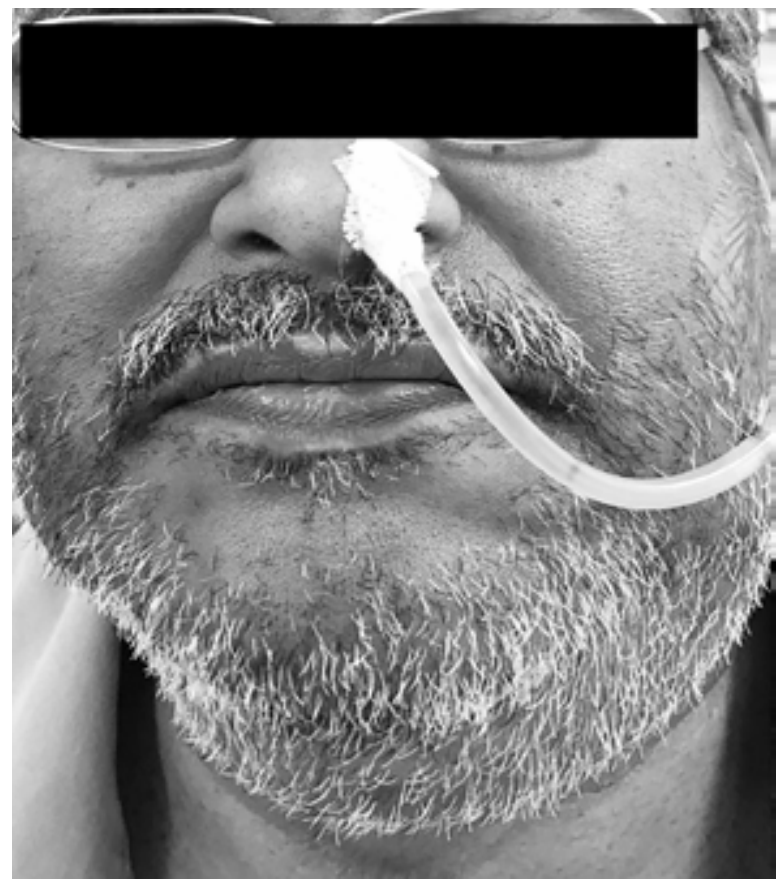

Fig. 2. Submental collection post drainage 
swelling. Repeated CT scan revealed a collection over the submental region (Fig. 2), with resolved previous collection over the parapharyngeal and peritonsillar region. Incision and drainage of the submental space were done under general anaesthesia, with $10 \mathrm{cc}$ of pus drained. A corrugated drain was inserted, and daily flushing with povidone was performed over the submental and intraoral site. Pus culture and sensitivity from both intraoral and submental regions revealed Staphylococcus aureus which was sensitive to amoxicillin/clavulanic acid. The patient was then discharged 2 weeks after admission, in a good condition, with oral antibiotics (amoxicillin/clavulanic acid). Subsequent follow-up revealed a healed intraoral and neck wound.

\section{DISCUSSION}

Deep neck infections usually involve the neck structures which are surrounded by multiple layers of cervical fascia. They may occur following the lymphatic spread of an infection in the oral cavity, face, superficial neck spaces, suppurative cervical lymphadenopathy, and penetrating trauma. Odontogenic infections can easily spread via the pathway of least resistance to the adjacent potential space, and subsequently deeper neck space. Odontogenic infections commonly spread into the submandibular, masseteric and sublingual spaces ${ }^{(4)}$. As in our patient, infection which occurred following dental extraction lead to a buccal abscess, submasseteric abscess, and subsequently spread into the parapharyngeal space.

Having said that, extension of infection from the masseteric space and submandibular space results in lateral pharyngeal space or parapharyngeal space infections ${ }^{(5)}$. The parapharyngeal space is inverted cone-shaped, with its apex at the greater cornu of the hyoid bone, and its base at the skull base. This space is then divided by the styloid process and its muscles into two compartments: the anterior prestyloid space containing muscles, lymph nodes with connective tissues, and the posterior retrostyloid space containing the great cervical vessels and nerves ${ }^{(5-7)}$. Anterior prestyloid compartment abscesses usually result in trismus, medialisation of the lateral pharyngeal wall, dysphagia and swelling over the parotid gland, and retromandibular swelling, which is similar to the finding in our patient. In contrast, posterior compartment abscesses usually have no trismus but more to posterior lateral pharyngeal wall medialisation and parotid swelling ${ }^{(8)}$.

The fastest and easiest way to diagnose deep neck infections is via CT scan neck which provides information on involved neck spaces, and extension along with airway examination $^{(9)}$.

Parapharyngeal abscesses should be managed promptly and accurately via incision and drainage along with broadspectrum antibiotics. Emergency incision and drainage of abscess collection should be done to prevent fatal airway complication and abscess extension into the retropharyngeal space, which may lead to mediastinitis. In this case, the pus culture and sensitivity result was Staphylococcus aureus. A study by Wang et al. revealed 119 out of 157 patients had a positive culture and sensitivity report for the pus taken from odontogenic infection sites, which showed mixed infections with a variety of Gram-positive and Gram-negative $\operatorname{organisms}^{(8)}$. Prompt management is definitely life-saving. Any delay in the treatment of a parapharyngeal abscess causes life-threatening airway compromise, mediastinal infection, vascular complications, septicaemia and mortality ${ }^{(10)}$.

\section{CONCLUSION}

Despite being common, odontogenic infections may be complicated, with deep neck space infection, if not treated promptly. Hence, high clinical suspicion is required amongst attending physicians so as to avoid life-threatening complications.

\section{Conflict of interest}

The authors do not report any financial or personal affiliations to persons or organisations that could adversely affect the content of or claim to have rights to this publication.

\section{References}

1. Viera F, Allen SM, Stocks RM et al.: Deep neck infection. Otolaryngol Clin North Am 2008; 41: 459-483.

2. Lee YQ, Kanagalingam J: Bacteriology of deep neck abscesses: a retrospective review of 96 consecutive cases. Singapore Med J 2011; 52: 351-355.

3. Tuncturk FR, Uzun L, Kalcioglu MT et al.: Carotid sheath abscess caused by a tooth decay infection on the opposite side. Case Rep Otolaryngol 2015; 2015: 739630.

4. Chow AW, Roser SM, Brady FA: Orofacial odontogenic infections. Ann Intern Med 1978; 88: 392-402.

5. Paonessa DF, Goldstein JC: Anatomy and physiology of head and neck infections (with emphasis on the fascia of the face and neck). Otolaryngol Clin North Am 1976; 9: 561-580.

6. Hora JF: Deep neck infections. Arch Otolaryngol 1963; 77: 129-136.

7. Rabuzzi DD, Johnson JT: Diagnosis and Management of Deep Neck Infections: A Self-Instructional Package from the Committee on Continuing Education in Otolaryngology. American Academy of Otolaryngology, Washington, DC 1978: 23.

8. Wang J, Ahani A, Pogrel MA: A five-year retrospective study of odontogenic maxillofacial infections in a large urban public hospital. Int J Oral Maxillofac Surg 2005; 34: 646-659.

9. Yilmaz S, Bas B, Ozden B et al.: Deep neck infection after third molar extraction. J Istanb Univ Fac Dent 2015; 49: 41-45.

10. Gani AN, Abdullah A, Hazim MYS et al.: Parapharyngeal abscess in immunocompromised patients. Med \& Health 2007; 2: 158-163. 